\title{
Towards Designing an Intercultural Curriculum: A Case Study from the Atlantic Coast of Nicaragua
}

\author{
Patricia Daniel \\ University of Wolverhampton, UK
}

\begin{abstract}
One of the challenges still to be met in the $21^{\text {st }}$ century is that of genuinely embracing diversity. How can education help to overcome the barriers that continue to exist between people on the basis of language, culture and gender? This case study takes the Atlantic Coast of Nicaragua as an example of a multilingual/multiethnic region and examines how the community university URACCAN is contributing to the development of interculturality. It describes participatory research that was carried out with university staff and students with the intention of defining an intercultural curriculum and appropriate strategies for delivering such. One model used as a basis for discussions was the Model for Community Understanding from the Wales Curriculum Council, which emphasises the belonging of the individual to different communities or cultures at the same time. Factors supporting the development of an intercultural curriculum include the university's close involvement with the ethnic communities it serves. However, ethno-linguistic power relations within the region and the country as a whole, still militate against egalitarianism within the university. The research highlights the importance of participatory pedagogy as the basis for promoting interculturality and achieving lasting social transformation.
\end{abstract}

\section{Introduction}

One of the challenges to be met by educators in the $21^{\text {st }}$ century is that of genuinely achieving unity in diversity. We still live in a world where ethnic conflict and violence flourish, with a resulting increase in numbers of migrants and refugees. How can education help to overcome the barriers that continue to exist between people on the basis of language, culture and gender? Documentation of projects set up by majority groups within the school sector across Europe (see Reid and Reich, 1992) and other parts of the world, indicates some progress. Perhaps ways forward can also be found in initiatives from minority communities themselves. In Wales, Welsh language rights and the

Patricia Daniel is a Senior Lecturer at the Centre for Rural Developmental and Training, School of Education, University of Wolverhampton. 
development of $y$ cwricwlwm cymreig (the Welsh Curriculum) have been accompanied with a looking outward to other minority groups in Europe and beyond (Curriculum Council for Wales, 1992). Links with the University of the Autonomous Regions of the Atlantic Coast of Nicaragua have pointed us to new ways of providing community education. The research exercise described in this paper is in itself, an example of interculturality in action as it formed part of ongoing links between two historically marginalised regions.

\section{Background to the Study}

The Autonomous Regions of the Atlantic Coast of Nicaragua comprise about $50 \%$ of the country's surface area but less than $10 \%$ of its population. The area contains most of the natural wealth of Nicaragua - timber, fishing and mining although this has largely been under the control of the central government (located in the Pacific side of the country) and foreign companies. Because of the dense forests and mountains in the centre of the country, the Atlantic side has historically been isolated from the rest.

There are six identified ethnic/linguistic groups, although there are racial overlaps between these. The figures below are quoted from the URACCAN mission statement, 1998:

\begin{tabular}{|c|c|c|}
\hline Mestizo: & $\begin{array}{l}\text { Spanish speakers from the Pacific side, found } \\
\text { throughtout the region }\end{array}$ & 120,000 \\
\hline Miskito: & $\begin{array}{l}\text { Indigenous Indian people, mixed with other } \\
\text { groups, found mainly in the North }\end{array}$ & 70,000 \\
\hline Creole: & $\begin{array}{l}\text { Afro-Caribbean people, mixed with European, } \\
\text { mainly in the South }\end{array}$ & 50,000 \\
\hline Mayangna: & $\begin{array}{l}\text { Indigenous Indian people, tending to live in self- } \\
\text { contained communities in the North }\end{array}$ & 12,00 \\
\hline Garifuna: & North Indian mixed with Afro-Caribbean & 3,00 \\
\hline Rama: & Indigenous Indian people, tending to live in self- & 1,00 \\
\hline
\end{tabular}

The national language of Nicaragua is Spanish, which is the first language of the majority population. However, according to the Autonomy Law passed by the Sandanista government in 1987, all peoples have the right to use their own mother tongue. A 'bilingual intercultural education' program, established at that time by teachers on the Atlantic Coast, provides early primary education in English, Miskito or Mayangna for some 6000 of the Atlantic Region's children (Feeland and Maclean, 1995). The adult literacy campaign of 1980-81 produced materials in these 3 languages as well as in Spanish. Since 1992, there has been an elected Regional Council that ensures the observance of the rights of the indigenous peoples of the Atlantic Coast. However, the area still comes under central government control.

Against this background, the University of the Autonomous Regions of the Caribbean Coast of Nicaragua (URACCAN) was set up in 1994 with the vision 
of 'developing the human resources of the area in order to manage the natural resources.’ Its objectives include the following (see URACCAN, 1998):

1. to strengthen the ethnic and cultural identity of each community

2. to serve as an academic reference point for intercultural and pluricultural education.

In order to serve the whole Atlantic community, the university has three main campuses with outlying branches within communities. Because of the distribution of the distinct ethic groups, the ethnic/linguistic composition of the three campuses varies from one to the other, although Spanish is the medium of instruction in all of them. The university offers five academic (degree level) programs which are pertinent to the needs of the regions: B.Sc. in Agro-Forestry; Administration; Sociology (with a focus on Autonomy); B.Ed. in Educational Sciences; and, Bilingual Education. All students are timetabled for Spanish, English and Miskito.

The programs are all part-time since many students hold responsible jobs in the region and few can afford to study full-time. It should also be emphasised that the full-time staff at each campus is small in number; most of the teachers have professional jobs elsewhere and only teach part-time. Often, teachers are themselves following a degree course in their spare time.

URACCAN also runs intermediate level programs for community leaders and community workers, for example, the Diploma in Gender and Development and the Diploma in Indigenous Human Rights. These are held in the communities and organised on a modular basis, with short intensive courses to make them as accessible as possible.

\section{Participatory Research: Purpose and Methodology}

The research took place as part of the developing links between the University of Wales at Bangor and the URACCAN. Links began in 1992 when one of the founding members of the URACCAN visited Wales for the first time and similarities between the two regions - Wales as part of the UK and the Atlantic Coast as part of Nicaragua - became clear (both are historically marginalised regions). During later exchange visits, the similarities have been explored in conferences and seminars to mutual benefit (see Daniel 1996a, 1996b).

The research was carried out in response to a specific request from URACCAN for support in the area of intercultural gender-sensitive curriculum. The objective was to carry out a diagnostic on the present curriculum and pedagogy in use at URACCAN, with reference to issues of language, culture and gender-sensitivity. The diagnostic involved the following methods:

- $\quad$ workshops with curriculum coordinators

- $\quad$ workshops with teaching staff

- a questionnaire to first year degree students

- observation of classes

- focus group discussions with students 
- one-on-one discussions with key staff members and individual students

- $\quad$ analysis of teaching/learning materials

The approach taken was that of activist participatory research inspired by Freire (1972), using dialogue and joint research to enhance awareness and confidence and to empower participants to take transformatory action. Freire's 'pedagogy of the oppressed' was also the basis of the award-winning Nicaraguan literacy crusade and thus the philosophy is not new to Nicaraguan educators. The research also reflected the participatory learning approach (PLA) developed, for instance, from Chambers (1997).

\section{Results}

The results of the study were disseminated in a report (see Daniel, 1999) and some of the issues raised such as those discussed below, will be followed through by students as dissertation topics.

\section{A definition of interculturality}

In the workshops with teachers, we worked with a spiral model of interculturality which is taken from the Curriculum Council for Wales Guidelines for Community Understanding (see Figure 1). This model, proposed as the basis for a cross-curricular dimension in school education in Wales, takes the individual as its starting point. Since everyone has different experiences and influences, we can see the individual as belonging to an idioculture of one. Viewing interculturality as a spiral, we see how it is possible for the individual to belong to many different communities or cultures at the same time. Thus personal identity is per se, intercultural rather than monocultural, as it is often perceived.

This model takes us away from the traditional view of a culture as closed, unchanging and separate. The traditional view is that relations between two cultures is one of 'otherness', difference, lack of understanding, hostility and conflict. The spiral shows that it is possible for communities to be interlinked and harmonious - while recognising that change is a characteristic within all communities and this can be a cause of conflict between individuals who respond more or less slowly to change. The spiral model is well suited to the pluri-ethnic reality of the Atlantic Coast, where, in fact, inter-marriage over many years means that individuals do belong to more than one ethnic community as well as to other social, political or geographical groups. Gender is another variable/ community that interfaces with all the other communities/cultures to which an individual belongs. Gender can therefore be seen as an integral part of interculturality in this model.

At the basis of the intercultural educational process, then, must lie the nurturing of relations of respect and equality between individuals. In order for this to be achieved, existing hierarchies of power (relating to gender, language, ethnicity, ability etc.) need to be challenged and changed. In one of the workshops, as the participants developed their own spiral for the Atlantic Coast, 
they emphasised the importance of two particular aspects of community understanding/interculturality:

- political consciousness

- $\quad$ active citizenship

\section{Intercultural curriculum and intercultural pedagogy}

All institutions to a certain extent create their own culture. The desired nature of the culture of the URACCAN was what we explored in the curriculum workshops with degree coordinators. In our discussions, it was agreed that the curriculum does not only include the obvious aspects such as program and content. The coordinators emphasised a 'much wider definition of curriculum (which) avoids the assumption that 'the important learning takes place by means of lessons and subjects' (Lawton, 1975). This also includes consideration of the human resources, staff, students and community.

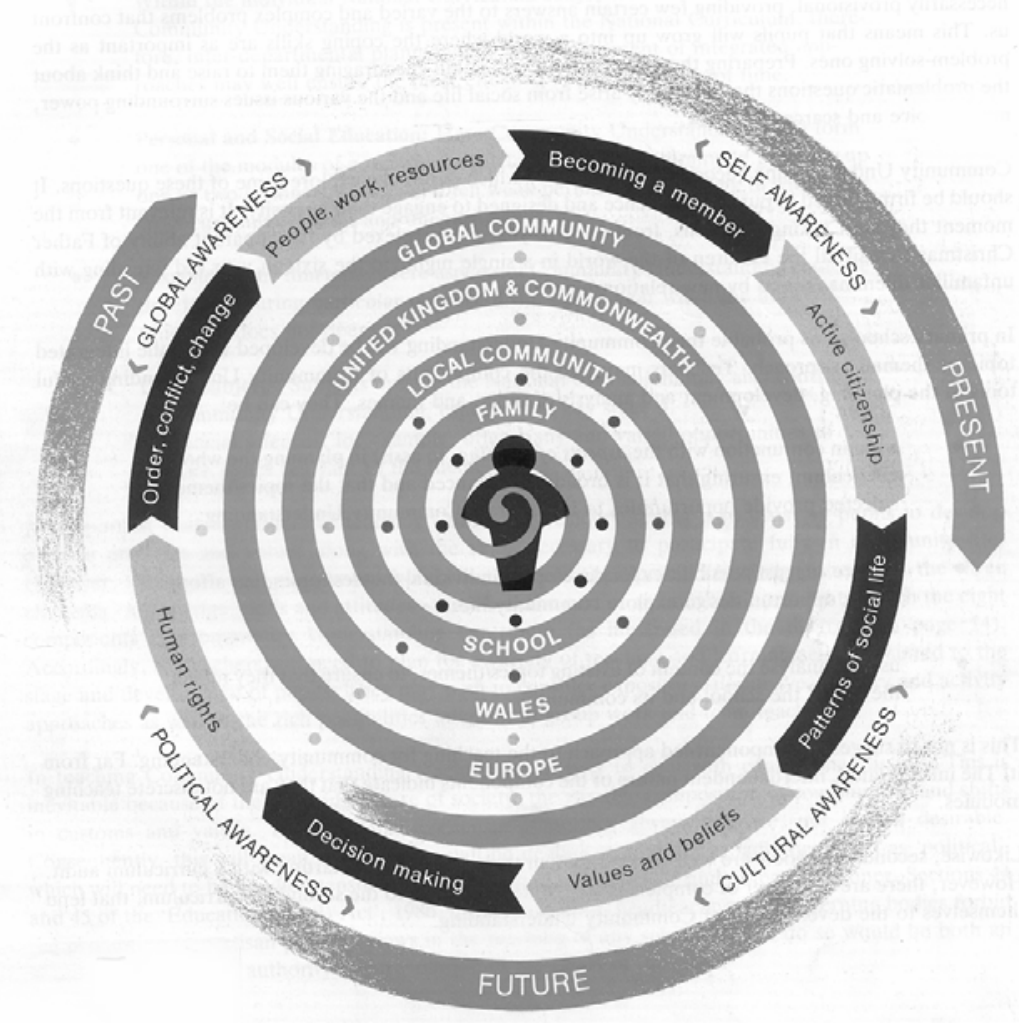

Figure 1

A Model for Community Understanding.

From Advisory Paper 11 Community Understanding, Curriculum Council for Wales, 1992 


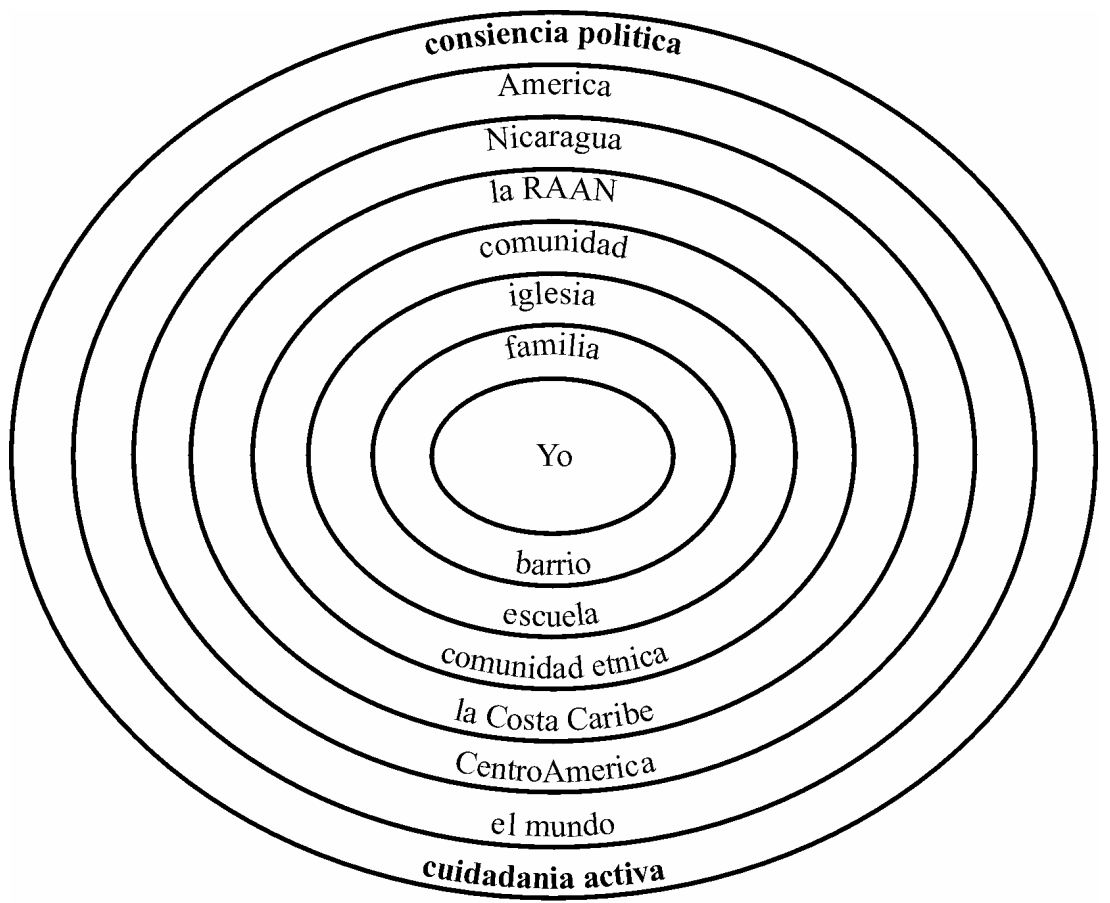

El Espiral Intercultural de la RAAN

Figure 2

The Intercultural Spiral of the Northern Autonomous Atlantic Region (RAAN) produced in one of the workshops

\section{The curriculum}

- the program and content

- learning objectives

- teaching/learning strategies

- organisation and administration

- methods of assessment

- resources such as books, materials, equipment.

- $\quad$ previous experience of learners

- $\quad$ language/s and language use

- teacher-learner relationships

- inter-institutional relationships

- participation of different sectors (from within and without - for example, community groups) 
As regards the objectives of an intercultural curriculum, a consensus was agreed on the following outcomes.

\section{Students will learn to:}

- acknowledge diversity and value difference

- live in harmony and respect within a multi-ethnic society

- $\quad$ understand and preserve the history, languages and cultures of the Coast and of the world

- $\quad$ recognise and claim their rights

- understand gender relations and other aspects of power

- promote equal opportunities and expectations between men and women

- $\quad$ use their own and other languages of the Coast

- use technology appropriate to the region

- carry out original research and produce new knowledge

Discussions with staff were also helpful in defining an appropriate pedagogy- the teaching/learning processes for an intercultural curriculum through which social transformation can be achieved (Freire,1972). The suggestions emphasise relevance, participation, egalitarianism and change.

\section{An intercultural pedagogy:}

- creates new relations of equality, destroying the traditional relations of power

- develops new ways of being, new expectations of what it is to be a man or a woman

- promotes participation and a democratic environment in which everyone can express their opinions

- $\quad$ is accessible to all and responds to everyone's needs

- $\quad$ is based on the experience of the students

- is relevant to life and work of the students on a regional and inter/national level

- $\quad$ is constructive- with the teacher as facilitator, rather than the expert

- $\quad$ is inclusive - provides access to all; everyone has the same opportunity

- $\quad$ respects individual differences

- $\quad$ is motivating and provides incentives for all

- $\quad$ is multicultural and multilingual

Responses from the student questionnaire confirmed the need for a more participative approach which involves elements such as small groupwork, problem-solving, student contributions, exchange of personal experiences and cultural knowledge. Such methods would help students overcome their reserve, develop relationships of friendship, and 'reduce egoism and pride' (Daniel, 1999: 29). 


\section{Strengths and opportunities supporting an intercultural curriculum}

Through a SWOT analysis, we identified the internal strengths and weaknesses of URACCAN as regards delivering an intercultural curriculum, as well as the external opportunities and threats. On the positive side, the following strengths and opportunities were identified:

- the university has autonomy in terms of establishing its curriculum and its degree courses are all relevant to the needs of the region

- through its 3 main campuses, it is located in the heart of different communities

- the B.Ed. program in Intercultural Bilingual Education is highly strategic in terms of the future of the region. It raises the profile of issues of language and culture, enhances the teaching skills in schools and thus, contributes to a stronger educational foundation for the next generation

- URACCAN has four research institutes working: i)on linguistic and cultural recovery projects; ii)traditional medicine; iii)autonomy; and iv) natural resources of the region

- the university has good links with a range of organisations (NGOs, ethnic community groups, women's groups etc.) and the opportunity to develop collaborative projects

- the students are actively involved in research projects in the communities, often in collaboration with other organisations, and all will carry out community-oriented research for their dissertations

- the teaching staff reflects a good gender balance as well as the pluriethnic/linguistic context

- the university recognises the need for integrating a gender perspective into the curriculum

- the university has become a focus of interest for academics from abroad, because of its involvement with the local communities and its intercultural ethos, and this presents an opportunity for exchange, support and development

- from the outset, the university has been involved in the autonomy struggle and it plays an important part in the region's history.

\section{Weakness and threats hindering the delivery of an intercultural curriculum}

As regards internal weaknesses hindering the delivery of an intercultural curriculum, two main aspects were identified. The first relates to staffing: many of the teachers are not trained in methodology at all, especially those working part-time and there is a specific need for training and staff development in the areas of interculturality, bilingualism and gender-sensitivity. Resistance of some of the teaching staff to changing their teaching style was noted. Another area is the lack of appropriate teaching/learning resources to support a change in pedagogy. Administration was seen to lack understanding of the problems. Poor communication between the 3 campuses and the central office (in the capital, 
Managua) has meant difficulty in sharing experiences, ideas and material resources.

Externally, there are two main threats to the continued success of the university itself. One is the present political situation whereby the right-wing government, elected in 1990, is backtracking on the rights awarded to the Atlantic Coast in the Autonomy Law passed by the government in 1987, in the areas of health and education, as well as in control over communal lands and natural resources of the region. The other threat is the constant need to look for outside funding to keep the project going, despite the fact that URACCAN is recognised within the state system and receives some central support.

Lack of acceptance among the communities for the concept of intercultural bilingual education in general, was also noted as a threat. The reasons for this are complex. Lack of resources in the school sector means that there are problems in implementing the program of intercultural bilingual education effectively at school level and this causes concern among parents. The central government (through the Ministry of Education) has taken these problems as an excuse to bring Spanish speaking teachers over from the Pacific side to work in primary schools on the Atlantic Coast, replacing local teachers from the indigenous communities. The B.Ed. program in Intercultural Bilingual Education was not supported by the Ministry of Education and many school teachers were dissuaded or prevented from attending the course. Sensitisation programs are being carried out in the North (and suggested in the South) in order to help parents and communities develop an understanding of the importance of intercultural bilingual education for the future of the region, and to encourage their participation in lobbying central government for greater support.

\section{Interculturality and language}

Another threat comes from within the regions themselves - the complex ethnolinguistic hierarchy which has developed historically through contact with outside peoples. As Freeland (1993:72) observes, 'Different interventions privileged different groups, altering relations between them all and giving rise to a complex of inter-ethnic divisions and rivalries...'. This hierarchy is still reflected within the university and is a serious weakness in terms of delivering an intercultural curriculum, despite all the university's research on linguistic recovery and the inclusion of minority languages in degree courses. The issue of language arose in all discussions with students and it became clear that the domination of the Spanish language as a lingua franca in the Atlantic Coast and the university, continues to undermine the status and respect awarded to minority languages. There is the additional problem of the local language pecking order whereby, for example, English is seen as more important than Miskito, and this is reflected in their weighting in the curriculum: only 2 semesters of Miskito as compared to 6 of English. Students who speak Spanish as a second language are often disadvantaged in class and in written assignments because they find it more difficult to express themselves in Spanish. One of the teachers recognised that: 
Sensitisation of staff is needed because often we treat students as dunces if they don't reply adequately, without taking into account that language is a factor (quoted in Daniel, 1999:20).

This problem was also recognised by students from the range of ethno-linguistic backgrounds; they recommended that explanations could be given in their first language if necessary, either by the teacher or by other students. As well as helping individual students, the use of minority languages in class would also provide more exposure to their classmates 'and they would be encouraged to learn them.' Students highlighted that language skills are important for carrying out research in the communities. Those students (e.g. Spanish speaking Mestizos) who do not speak minority languages are actually at a disadvantage in this situation and this may affect the effectiveness of the research. Both Creole and Mestizo students recognised the importance of learning English, while the Creole students said: 'we only pass through Spanish because we have to' (see Peters, 1999).

Staff from linguistic minorities are also disadvantaged in the university environment because of the lingua franca and this can affect the maintenance of egalitarian relations. Spanish speaking teachers could attend classes to develop skills in Creole, Miskito or Mayangna and many expressed their willingness to do so. But there is more to a language than just speaking it. Language awareness has been found to be equally, if not more important, in the development of a truly intercultural community (Daniel 1998). Awareness training for all staff was recommended by the coordinators at both campuses: this would include, for instance, the importance of first language for identity and well-being as well as educational achievement; language rights of the region, and an exploration of interculturality in the classroom.

\section{Interculturality and gender}

Another complexity is the interface between gender and culture. Teachers pointed out that gender relations within the classroom still reflected a traditional male dominance. Students also felt that although 'women have an equal right to, they often don't in fact make equal contribution in class' (Daniel, 1999: 28). Lack of participation was seen by students not only as a factor of gender but also a factor of culture, motivation or personal shyness. These issues may equally relate to the composition and the subject of the class. Students pointed out that when women were in a majority in the class, the men contributed less and seemed less motivated. In one Agro-Forestry class, only one student was female. Second Year students indicated that female students were more timid and contributed less. This was attributed to the traditional Miskito culture, where women have defined roles distinct from those of men and are not traditionally active in decision-making fora. But this could also be said of the Creole and Garifuna communities (see Garcia, 1993). 
Students recommended an interactive pedagogy, including small groupwork and cultural exchange, as a way of overcoming shyness. In general it was noted that small groupwork involving men and women exchanging knowledge and experience enabled them to carry out tasks to a higher level:

Men and women contribute in different ways... when we work together we form better ideas and share different perspectives ... we get better results. (Daniel, 1999: 28)

On one campus, there are Agro-Forestry classes comprising equal numbers of men and women. The number of women in the program is a positive force for change in perceptions of women's contribution to agriculture, forestry and fishing. One of the teachers described how fieldwork provided valuable cultural exchange and the opportunity to develop new perspectives on all sides.

At present, culture is not considered as an integral part of the Agro-Forestry degree. However, considering and comparing traditional practices more explicitly may help to identify the kinds of support and interventions that can be most effective. The university has been involved in projects aimed at introducing new models of agro-forestry as part of an economic strategy of diversification. These include the promotion of women's traditional activities in the kitchen garden, in order to raise their economic independence and decision-making status within the household, as well as enable them to make a greater contribution to the development of the community and the region (Pro Patio, 1999). Such moves have met with resistance from the communities involved. This might be explained by a reluctance on the part of men, to taking on new types of economic activity, especially those that are seen traditionally as a women's tasks (and thus not considered 'work'). Yet, while men go further afield to find 'work', women are left with responsibility for the household, subsistence farming and community needs. Examining these gender roles and expectations has been difficult in diploma courses for Community Leaders (who are mainly men).

Sociology students have been involved in a large scale survey into the productive farming, forestry and fishing activities of different communities as part of a UNESCO funded project. There is a clear opportunity for cross-disciplinary work in analysing the results with Agro-Forestry students and making recommendations for future productive activities.

Collecting disaggregated statistics on enrolment each year will be useful in helping to prioritise strategies for encouraging a better gender and ethnic balance in all the courses. In the B.Sc. Administration program, it was also clearly possible to integrate aspects of gender and culture into the different units. For example Human Resource Management could include statistical analysis of the recruitment of women and ethnic/linguistic minorities into regional business and NGOs; attitudes regarding employment for women and ethnic/linguistic minorities; examining the practice of organisations as regards pregnancy, maternity leave and the right for women to return to work.

Staff development workshops for university teachers are being planned in collaboration with women's organisations and NGOs. These courses need to 
include practical analysis of how the staff can integrate a gender perspective in the content and methodology of their courses, using small interdisciplinary groups to examine specific topics. It will be important to focus on gender and development, especially related to students carrying out community research for their monographs. The workshops need to consider the roles and responsibilities of men and women in the different ethnic communities and how new expectations and opportunities for women (and men) may impact on traditional values.

\section{Strategies}

Strategies for use in multilingual classes were explored in the teachers' workshop in an experiential manner. Activities included: producing personal banners; brainstorming; production of an Atlantic Coast Community Understanding spiral; discussion of specific problems within the classroom related to language, culture and gender; small groups working on specimen plans for a cross-disciplinary lesson. Figure 3 summarises the classroom strategies that were provided as a basis for discussion. It was emphasised that planning needs to include consideration of gender and cultural aspects, as well as language use (see Figure 4). All programs of study need to be revised to include objectives specifically related to these aspects.

As a result of the workshop, teachers began to feel more empowered to deal with some of the problems identified. Especially notable in Bilwi campus was the initial resistance of Miskito speakers to the concept of allowing Miskito to be spoken in class to provide understanding and recognition. This was closely linked with the fear teachers felt about the central government's threat to replace indigenous teachers with Spanish speakers from the Pacific side. The teachers' perception of their own Miskito language and culture seemed to have changed through the workshop because its importance in the classroom and curriculum was emphasised. According to the written course evaluation, participants learned that:

It's not only in the bilingual schools that I can use my mother tongue as a teaching/learning tool.

To love my culture and to try to conserve it. I felt more identified with my people and with the struggle ...

However, participants still felt:

The need for permission from the government to develop my own language.

Limited, not able to use my language in the development of the classes I give.

\section{What did I learn?}

- Each individual is different and must be treated as such yet at the same time he or she can still work with people of different cultures and in different settings. 


\section{A Introductory Activities}

- Ground rules relating to use of languages, culture and gender issues

- Mutual explanation and discussion of cultures and of dominance between cultures and genders

\section{B Student activities}

- Groupwork in same language, culture, gender groupings

- Groupwork tasks in mixed groups which require students to exchange personal experience

- Student presentations given bilingually

- $\quad$ Student presentations on topics relating to their own gender, culture and work experience

- whispering: student interprets for fellow student in class

\section{Assessment}

- Some assignments produced in students mother tongue

- Presentations (oral assignment) in different languages

- Multiple choice questions on different languages*

D Materials

- Handouts of key points in different languages*

- Glossaries for key terms*

\section{E General Strategy}

Taking a comparative/contrastive approach to language, culture, gender in relation to the topic
A Actividades introductorias

- Reglas de juego relacionadas con el uso de idiomas y perspectivas multiculturales y de genero

- Explicaciones mutuales y discusiones sobre culturas de los/las estudiantes y relaciones de poder entre culturas y generos

\section{B Actividades estudiantiles}

- Trabajo en grupo según idioma, cultura o genero

- Trabajo en grupos mixtos para intercambio de experiencias personales

- $\quad$ Presentaciones bilingües

- $\quad$ Presentaciones sobre asuntos relacionados a genero, cultura y experiencias en el trabajo

- Interpretacion a voz baja entre estudiantes durante la clase

C Evaluación

- Algunos ensayos en el idioma materna del estudiante

- Presentaciones en distintos idiomas

- Evaluación de conocimientos (por ejemplo preguntas cortas/opcion multiple) en distintos idiomas*

D Materiales

- hojas para llevar conteniendo puntos claves en distintos idiomas*

- Vocabularios de terminología clave en distintos idiomas*

\section{E Estrategía general}

Tomar un enfoque comparativo y contrastando a lenguaje, cultura y genero relacionado al asunto estudiado

Figure 3

Strategies for Intercultural Multilingual and Gender Sensitive Teaching and Learning 
1 Have I established ground rules in the classroom which ensure mutual respect;

- $\quad$ use of non racist, non-sexist language;

- $\quad$ allowing everyone to express their views

- not allowing anyone to dominate?

2 Have I incorporated these dimensions of EIBG in my planning?

- Lesson plans;

- $\quad$ choice of material;

- $\quad$ predicting possible problems.

$3 \quad$ Have I developed a strategy for ensuring that classroom language reflects the dimensions of EIBG?

- Teacher language;

- $\quad$ student language;

- $\quad$ spoken language;

- $\quad$ written language

4 Have I planned for all the language resources of the classroom to be used?

- $\quad$ Have I planned to draw on students personal experiences?

5 Have I considered the dimensions of EIBG in my classroom management?

- $\quad$ Use of open questions;

- $\quad$ giving equal attention and time to all students;

- $\quad$ setting up collaborative problem solving tasks where students need to take turns, listen and support each other

6 Have I ensured that my resources use positive images and positive role models within the Nicaraguan multiethnic context?

Where using existing resources:

Have I planned to highlight the bias and exploit it as a teaching point?

7 Have I planned to include students in establishing lesson objectives with specific reference to EIBG?

And to feed back to students how they have achieved these?

8 Have I planned evaluation strategies with students which provide feedback on the above?
1 He establecido reglas de juego en la aula para asegurar el respeto mutual?

- Uso de lenguaje no-racista, no-sexista

- $\quad$ Que todo el mundo pueda expresar sus opiniones

- $\quad$ Que nadie domine

2 He incorporado las dimensiones de la EIBG en mi planificación?

- Planes de clase

- $\quad$ Selección de materiales

- Anticipar problemas potenciales

3 He desarrollado unas estrategias para asegurar que el lenguaje de la clase refleja las dimensiones de la EIBG?

- $\quad$ Lenguaje del docente

- $\quad$ Lenguaje de los/las alumnos/as

- Lenguaje oral

- Lenguaje escrito

4 He planificado como vamos a utilizar todos los recursos de la clase?

- Idiomas

- $\quad$ Experiencias personales

5 He considerado las dimensiones de la EIBG en mi manejo de clase?

- Uso de preguntas abiertas

- Dar atención y tiempo igual a todos/as estudiantes

- $\quad$ Crear tareas colaborativas para resolver problemas donde los/las estudiantes toman su torno, escuchan y se apoyan?

6 He asegurado que en los materiales son referencias positivas; imágenes y modelos positivos adentro de la realidad multietnica nicaragüense?

Y/O Si es necesario utilizar materiales conteniendo perjuicios o términos negativos: He planificado como enfocar en los perjuicios y explotarlos como punto de aprendizaje?

7 He planificado como involucrar los/las estudiantes para establecer los objetivos de la unidad con referencia a la EIBG? Y como dar feedback a los/las estudiantes sobre sus logros?

8 He planificado estrategias de evaluación a ser utilizadas con los/las estudiantes para evaluar a todo lo arriba?

\section{Figure 4}

\section{Checklist for Integrating Intercultural Bilingual and Gender Dimensions into the Curriculum}


- How to understand and get along with all the people I have relationships with (at work, at university, at home).

- How to exchange experiences as part of a group.

How did I feel?

- That I am part of a community of co-existence of different languages and cultures but that we can listen to and understand each other with a shared voice.

- I felt strengthened and with confidence

- I felt good, motivated and identified with the theme

What do I still need?

- To learn more about the Coast culture and local languages

- To liberate myself from the status quo of only using Spanish in my classes

- $\quad$ To develop new strategies for a better male-female dynamic, better staff-student relationships and intercultural exchanges

What will I do differently now?

- $\quad$ The greater richness of diversity requires greater care in teaching preparation so that we get the best results for all our students

\section{Conclusion}

In conclusion, the participatory research exercise described in this paper high lighted the fact that the following components are necessary for intercultural curriculum to flourish:

- government support

- community sensitisation

- $\quad$ skilled and committed staff

- revolutionary pedagogy

- involvement of students in developing equality of language and gender

- disaggregated statistics

In the long-term, it was agreed that within the university, support and advice to staff should be provided in a variety of ways: for example, through an intercultural curriculum coordinator at each campus; exchange of experiences between campuses; development of teaching/learning resources; training of staff. In particular, cross-disciplinary workshops are seen as an effective method of reviewing course objectives and classroom methodology. The research also highlights that even in the short-term, training of staff is an important step in developing a shared awareness and understanding of interculturality and a commitment to change. This would depend on the participative dynamic which was an aspect of the transformative pedagogy we explored. It is particularly through this pedagogy that the wider objectives of an intercultural curriculum can be met. 


\section{Acknowledgement}

For her support and professional contribution, many thanks are due to Helen Peters of University of North London who co-facilitated the workshops, helped to record the research, and provided support to the university on the English curriculum.

\section{References}

Byram, M. (1991). Reflections on otherness, Times Educational Supplement, March 15 p. 43.

Chambers, R. (1997). Whose Reality Counts? Putting the Last First. London: Intermediate Technology Publications.

Curriculum Council for Wales (1992). Advisory Paper 11. Community Understanding, Cardiff: Curriculum Council for Wales.

Daniel, P. (1996a). We Share the Same Struggle. Women in Wales, Women in Nicaragua. Bangor: Môn and Arfon Central America Group.

Daniel, P. (1996b). Moving forward together. Women's projects in Nicaragua. Network Wales. June, 14-15.

Daniel, P. (1998). There's More to Welsh than Just Speaking It, Cardiff: NCH Action for Children Cymru.

Daniel, P. (1999). Report of the visit to review the intercultural bilingual gender-sensitive curriculum. Managua: URACCAN

Daniel, P. (forthcoming). Women networking: Crossing cultural boundaries. In Ellis, J. et al. (Eds) Working Class Women in International Context, Greenfield, MA: Greenfield Community College.

Freeland, J. (1993) “I am Creole, so I speak English.” Cultural ambiguity and the 'English'/Spanish bilingual-bicultural programme of Nicaragua's Atlantic Coast. In D. Graddol, L. Thompson and M. Byram (Eds) Language and Culture. Clevedon: BAAL and Multilingual Matters

Freeland, J. and Maclean, G. (1995) Final Report of the Mission to Evaluate the Bilingual Intercultural Programme, Managua: URACCAN.

Freire, P. (1972). Pedagogy of the Oppressed. Harmondsworth: Penguin

Garcia, A. et al. (1993). La Participacion Politica de la Mujer en las Regiones Atuonomas, Managua: Centzontle

Lawton, D. (1975). Class, Culture and the Curriculum. London: Routledge and Kegan Paul

National Assembly of Nicaragua (1987). Autonomy Statute for the Regions of the Atlantic Coast of Nicaragua. Law No. 28, Managua: (reprinted in English by Oficina de Desarrollo de la Autonomia de la Costa Atlantica de Nicaragua, 1994).

Peters, H. (1999). Report on the visit to review the English Language provision at URACCAN Bluefields and Bilwi campuses, in Daniel, P. (1999) Report of the visit to review the intercultural bilingual gender-sensitive curriculum, Managua: URACCAN.

Pro Patio (1998). Entrenamiento- Estudio de Patio Managua: Pro Patio.

Reid, E. and Reich, H. (1992). Breaking the Boundaries Clevedon, UK: Multilingual Matters.

URACCAN (1998). Mission Statement. Managua: URACCAN. 